\title{
EVALUATION OF 3-YEARS COURSE OF SUBLINGUAL IMMUNOTHERAPY WITH EXTRACTS OF CAT EPITHELIUM IN PRE-SCHOOL CHILDREN
}

\author{
Sharikadze $O$. \\ Shupyk National Medical Academy of Postgraduate Education, Ukraine \\ https://doi.org/10.35339/ic.6.4.216-220
}

\begin{abstract}
The article presents the results of a 3-year course of sublingual allergen immunotherapy with a lyophilized extract of cat epidermal allergens in preschool children with allergic rhinitis, rhino-conjunctivitis and bronchial asthma. New possibilities of component diagnostics were found, and in particular, the definition of the major Fel $d 1$ molecule as a direct indication for the start of therapy and use to assess the achievement of tolerance to the causative allergen. It was found that a 3-year course of sublingual allergen immunotherapy with lyophilized epidermal cat allergens for children with allergic rhinitis and/or bronchial asthma was characterized by a significant improvement in the clinical symptoms of the disease and a decrease in the level of Fel d1. A comparative analysis of the results of observing children with SLIT and without therapy proved that SLIT in children with allergic pathology associated with sensitization to cat epidermal allergens reduces the number of exacerbations and prevents the development of symptoms of bronchial asthma in preschool children. In addition, once again, high safety allergen immunotherapy efficacy in children has been proven.

Key words: preschool children, sublingual allergen immunotherapy, prevention, asthma, major allergens Fel $d 1$.
\end{abstract}

\section{Introduction}

Sublingual allergen immunotherapy (SLIT) is effective and safe treatment for children with allergic rhinitis, rhino-conjunctivitis and asthma. The efficacy of SLIT in the prevention of asthma in patients with seasonal allergic rhinitis is described. At the same time, to date, there is not enough information in the literature about the possibilities of prescribing SLIT in children less than 5 years of age, despite the fact that the start of the "atopic march" falls even at an earlier age. The "atopic march" well described in the medical scientific literature requires a further study. [5, 14]. In addition to food allergens, its development involves aero- or inhalant allergens, that are increasingly being considered as a significant etiological factor. Among them, a rather significant role belongs to animal epidermal allergens. The cat allergens have a special role among them.

Corresponding Author:

Olena Sharikadze, MD, Ph.D., Associate Professor

of the Department of Pediatrics No. 1,

Shupyk National Medical Academy

of Postgraduate Education, Kyiv, Ukraine, e-mail: sharikadzelena@gmail.com
Modern date show that the prevalence of allergic reactions associated with allergens in cats and dogs is $10-20 \%$ [4]. First of all, this is due to the annual increase the number of animal owners. In the scientific literature, allergens of animals and the properties of their vital products are already well defined. The main allergic component responsible for the development of allergic reactions in more than $90 \%$ of patients with clinical manifestations of allergy is Fel $d$. This is an uterokinin-like protein with a molecular weight of $38 \mathrm{kDa}$, which is found in the hair, dandruff, saliva, and lacrimal fluid of a cat, secretion of the anal glands, but absent in its urine and serum. Its secretion depends on the hormonal status and testosterone level - in males it is more than in females, and after castration the secretion of this protein decreases. The high activity of cat allergens and the high risk of allergic reactions after short-term contact, as well as data on the high activity of this allergen and the possibility of its transmission through contact with the owner of the animal, have been proven $[1,3,6,7,13]$. Moreover, the analysis of modern literature data indicates a significant lack of information regarding the treatment of this type of allergy, the possibility 
of using sublingual allergen-specific therapy (SLIT), especially in children [11].

2. Purposes, subjects and methods:

2.1. Purpose. To evaluate the efficacy of sublingual immunotherapy with extracts of cat epithelium in pre-school children and possibilities of component allergy diagnostics using SLIT.

2.2. Subjects \& Methods. As part of a prospective cohort study, the analyzed sample included 302 children aged 6 months to 7 years with clinical manifestations of allergic rhinitis (AR), rhino-conjunctivitis (ARC), bronchial asthma (BA), which depended on the allergens of a cat and / or dog.

Inclusion criteria: 1) Sensitization confirmed by skin prick test (SPT) and serum level of allergen-specific IgE measured using ImmunoCAP® (ThermoFisher Scientific, Uppsala, Sweden). The presence of a papule $\geq 3 \mathrm{~mm}$ in size and a serum level of specific IgE for Can f1, Fel d $1 \geq 0.35 \mathrm{kU} /$ $\mathrm{L}$ molecules were considered proven sensitization. 2) Complaints of the development of symptoms of rhinitis, rhino-conjunctivitis, cough, shortness of breath in contact with animals.

Children with polyvalent sensitization to various inhalation and food allergens were excluded from the study.

Due to the fact that in patients with true sensitization to major allergens, Can $\mathrm{f} 1$ there were no severe allergic manifestations in clinical history, SLIT was not recommended for these children. Sublingual allergen immunotherapy with lyophilized extracts of cat epithelium was performed in 16 patients with positive skin prick- tests and confirmed sensitization to major cat allergens Fel $d$ 1. These children were included in the $1^{\text {st }}$ observation group. 10 children who did not receive SLIT were included in the comparison group ( $2^{\text {nd }}$ group). Children in both groups also received protocol-based basic therapy. If necessary, 2nd generation antihistamines, inhaled betaagonists, IHCs and anti-leukotriene drugs were added to control respiratory symptoms.

The efficacy of the therapy was evaluated using a visual analogue scale (VAS) and the level of sIgE Fel $d$ 1, that were determined before the start of therapy and during the 3-year follow-up.

Clinical and laboratory characteristics of children of the $1^{\text {st }}$ and $2^{\text {nd }}$ examined groups are presented in Table 1.

STATISTICAL ANALYSES

The Statistical analyses of the means were evaluated using the software package "Statistica2014" and "Excel-2010". Nonparametric variables were analyzed using the Mann-Whitney paired test, while categorical variables were analyzed using the Fisher test.

\section{Conflict of interests}

The authors of the article declare no conflict of interest.

\section{Results and discussion}

The results of a three-year evaluation of the SLIT clinical efficacy of according to VAS indicators are presented in Table 2.

The analysis of the results showed that in patients of the 1st group means of the upper symptoms were significantly decreased: sneezing by 5.7 times $(p=0.041)$, rhinorrhea by 4.5

Table 1

Clinical and laboratory characteristics of the examined children

\begin{tabular}{|c|c|c|}
\hline Marks & $\begin{array}{c}1^{\text {st }} \text { group } \\
n=16\end{array}$ & $\begin{array}{c}2^{\text {nd }} \text { group, } \\
n=10\end{array}$ \\
\hline $\begin{array}{c}\text { Gender, n (\%) } \\
\text { - male } \\
\text { - female }\end{array}$ & $\begin{array}{l}4(66.7 \%) \\
2(33.3 \%)\end{array}$ & $\begin{array}{l}7(70.0 \%) \\
3(30.0 \%)\end{array}$ \\
\hline Age $(M \pm m)$, year & $4.7 \pm 0.5$ & $4.2 \pm 0.4$ \\
\hline Keeping the cat in the house & $2(33.3 \%)$ & $3(30.0 \%)$ \\
\hline $\begin{array}{c}\text { Clinical symptoms, } \mathrm{n}(\%)^{*} \\
\text { - nasal congestion } \\
\text { - conjunctivitis } \\
\text { - shortness of breath } \\
\text { - sneezing } \\
\text { - itching } \\
\text { - cough } \\
\text { - rhinorrhoea } \\
\text { - skin symptoms }\end{array}$ & $\begin{array}{l}6(100.0 \%) \\
6(100.0 \%) \\
5(83.3 \%) \\
4(66.7 \%) \\
4(66.7 \%) \\
4(66.7 \%) \\
1(16.7 \%) \\
1(16.7 \%)\end{array}$ & $\begin{array}{c}8(80.0 \%) \\
10(100.0 \%) \\
8(80.0 \%) \\
6(60.0 \%) \\
7(70.0 \%) \\
8(80.0 \%) \\
3(30.0 \%) \\
3(30.0 \%)\end{array}$ \\
\hline Monosensitized children, $\mathrm{n}(\%)$ after SPT & $3(50.0 \%)$ & $4(40.0 \%)$ \\
\hline 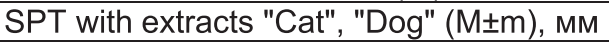 & $8.3 \pm 2.7$ & $8.5 \pm 1.4$ \\
\hline $\begin{array}{c}\text { slgE, } \mathrm{kU} / \mathrm{l}(\mathrm{M} \pm \mathrm{m}) \\
-F e l d 1\end{array}$ & $12.8 \pm 3.1$ & $15.1 \pm 4.2$ \\
\hline
\end{tabular}


Table 2

Means of VAS scale during the treatment of SLIT

\begin{tabular}{|c|c|c|c|c|c|c|c|c|c|c|}
\hline \multirow{2}{*}{$\begin{array}{c}\text { Marks, mm } \\
(0-100)\end{array}$} & \multicolumn{5}{|c|}{$\begin{array}{c}1^{\text {st }} \text { group, } \\
n=16\end{array}$} & \multicolumn{5}{|c|}{$\begin{array}{c}2^{\text {nd }} \text { group } \\
n=10\end{array}$} \\
\hline & $\begin{array}{c}\text { Before } \\
\text { treat } \\
\text { ment }\end{array}$ & $6 \mathrm{mo}$. & $12 \mathrm{mo}$. & $24 \mathrm{mo}$. & $36 \mathrm{mo}$. & $\begin{array}{c}\text { Before } \\
\text { treat } \\
\text { ment }\end{array}$ & $6 \mathrm{mo}$. & $12 \mathrm{mo}$. & $24 \mathrm{mo}$. & $36 \mathrm{mo}$. \\
\hline \multicolumn{11}{|c|}{ Upper symptoms } \\
\hline Sneezing & $29.6 \pm 12.7$ & $18.7 \pm 5.9^{*}$ & $12.8 \pm 3.2^{*}$ & $8.4 \pm 1.7^{*}$ & $5.2 \pm 0.5^{*}$ & $27.4 \pm 6.2$ & $20.9 \pm 6.8^{*}$ & $19.3 \pm 5.3^{*}$ & $19.8 \pm 6.3$ & $21.3 \pm 8.5^{\wedge}$ \\
\hline Rinorrhea & $15.8 \pm 3.8$ & $9.0 \pm 1.6^{*}$ & $5.8 \pm 1.0^{*}$ & $4.3 \pm 0.7^{*}$ & $3.5 \pm 0.2^{*}$ & $10.6 \pm 1.5$ & $7.2 \pm 2.1$ & $10.3 \pm 3.8$ & $8.5 \pm 1.8$ & $9.3 \pm 2.5^{\wedge}$ \\
\hline Itchy nose & $25.1 \pm 7.5$ & $17.3 \pm 4.2^{*}$ & $9.1 \pm 1.3^{*}$ & $7.8 \pm 2.1^{*}$ & $3.2 \pm 0.5^{*}$ & $27.4 \pm 6.8$ & $17.1 \pm 3.6$ & $16.7 \pm 4.2$ & $15.8 \pm 5.9$ & $18.5 \pm 5.1^{\wedge}$ \\
\hline \begin{tabular}{|l|} 
Nasal \\
congestion
\end{tabular} & 49 & $28.3 \pm 7.5^{*}$ & $19.1 \pm 4.2^{*}$ & $11.5 \pm 2.9^{*}$ & $\pm 0.7^{*}$ & 1.8 & $28.4 \pm 6.9$ & $19.6 \pm 4.3$ & $25.9 \pm 4.9$ & $21.4 \pm 7.2^{\wedge}$ \\
\hline Itchy eyes & $26.1 \pm 5.8$ & $15.3 \pm 4.3$ & $10.2 \pm 2.2$ & $7.8 \pm 1.7$ & $4.7 \pm 0.3$ & $23.7 \pm 4.7$ & $19.2 \pm 4.3$ & $15.8 \pm 4.9$ & $15.2 \pm 8.3$ & $18.9 \pm 5.7^{\wedge}$ \\
\hline $\begin{array}{l}\text { Conjunctival } \\
\text { hyperemia }\end{array}$ & $48.1 \pm 8.4$ & $31.2 \pm 5.9^{*}$ & $22.1 \pm 5.1^{*}$ & $14.2 \pm 3.1^{*}$ & $5.3 \pm 1.2^{*}$ & $46.3 \pm 10.8$ & $28.3 \pm 5.9$ & $26.2 \pm 7.3$ & $23.9 \pm 6.1$ & $26.1 \pm 11.3^{\wedge}$ \\
\hline Watering & $24.3 \pm 8.5$ & $18.3 \pm 4.3$ & $12.4 \pm 3.2$ & $8.1 \pm 2.5$ & $2.9 \pm 0.5$ & $28.3 \pm 7.6$ & $11.8 \pm 4.3$ & $14.5 \pm 3.2$ & $17.6 \pm 5.3$ & $20.8 \pm 4.5^{\wedge}$ \\
\hline \multicolumn{11}{|c|}{ Lower symptoms } \\
\hline Dyspnea & $56.1 \pm 18.3$ & $31.8 \pm 13.4$ & $19.5 \pm 7.2$ & $11.2 \pm 3.3$ & $6.5 \pm 1.6$ & $54.2 \pm 13.7$ & $37.1 \pm 10$. & $\angle 6.8 \pm 10.5$ & $33.2 \pm 11.1$ & $30.4 \pm 10.9^{\wedge}$ \\
\hline Cough & $39.4 \pm 9.2$ & $22.8 \pm 6.3^{*}$ & $171+50^{*}$ & $11.2 \pm 2.3^{*}$ & $4.1 \pm 1.9^{*}$ & $42.3 \pm 10.4$ & $351+12$ & $296+119$ & $32.4 \pm 13.1$ & $32.9 \pm 7.8^{\wedge}$ \\
\hline
\end{tabular}

$(\mathrm{p}=0.027)$, itching by $7.8(\mathrm{p}=0.01)$ and nasal congestion $10.2(\mathrm{p}=0.013)$ times to compare with the initial level (Table 2). During the therapy in the group of children with SLIT the symptoms of "itchy eyes" significantly decreased in $5.5(p=0.033)$, "conjunctival hyperemia" in $9.1(\mathrm{p}=0.028)$ and "watering" in $8.4(\mathrm{p}=0.036)$ times, respectively, compared with the initial values.

Figure 1 presents a general follow-up description of the upper and lower symptoms in children of both groups and a significant improvement is recorded secondary to SLIT.

Significant differences of the clinical symptoms, especially the fact of the development

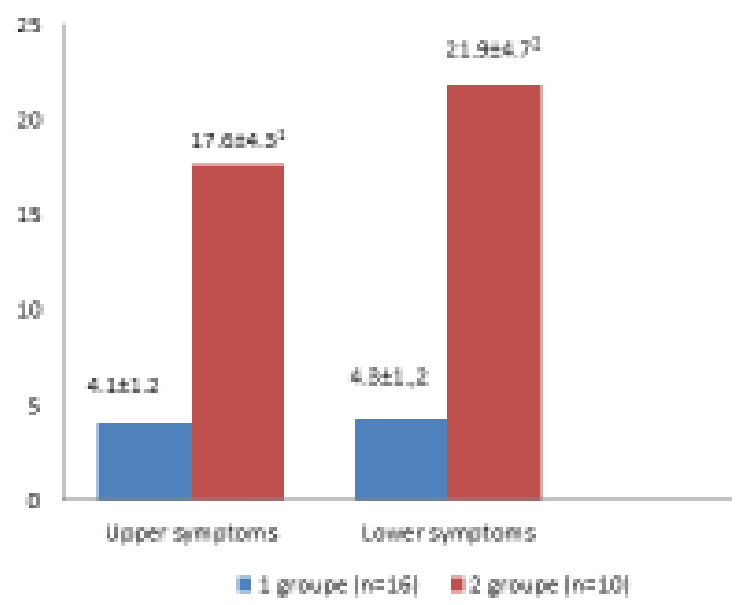

$1-p=0.032$ compared with the initial means; $2-p=0.015$ compared with the initial means.

Figure 1. Comparative characteristic of the results of a 3-year treatment in study groups with sensitization to pet allergens according to VAS indicators of bronchial asthma in 4 (40\%) children of the $2^{\text {nd }}$ group, despite the basic therapy, demonstrated the high effectiveness of SLIT as a method of preventing the progression of allergic pathology and the development of allergic asthma. It coincides with own observations among children of this age group who used SLIT with a mixture of house dust mites and data from foreign literature regarding older children $[6,10,11]$

In our opinion, an important factor, that shows SLIT efficacy, is "frequency of respiratory virus diseases". It decreased in the 1st group during the SLIT in the $2^{\text {nd }}$ and 3rd year, $3.0(p=0.042)$ and $3.4(p=0.037)$ times accordingly (Fig. 2). This fact confirms that SLIT has a preventive value in the development of upper respiratory tract infections.

Besides improvement VAS parameters in children of the first group compared with children of the second group, were recorded significantly decreased levels of the specific IgE for Fel $d 1$ by $17.9 \%(\mathrm{p}=0.011), 28.1 \%(\mathrm{p}=0.009)$ and by $50.8 \%(\mathrm{p}=0.003)$, respectively, compared with the initial values. In the children from the comparison group, there were no significant differences between the initial means and the means fulfilled after 3 years.

SAFETY REPORTING

Taking into account the age-specific characteristics of the examined children (37 years), the safety of SLIT is a priority in assessing this method According to the World Allergy Organization (WAO) guidelines during the study was not registered any systemic adverse events. Rare (6\%) local adverse events in the form of oral allergic syndrome (OAS) have been reported. 


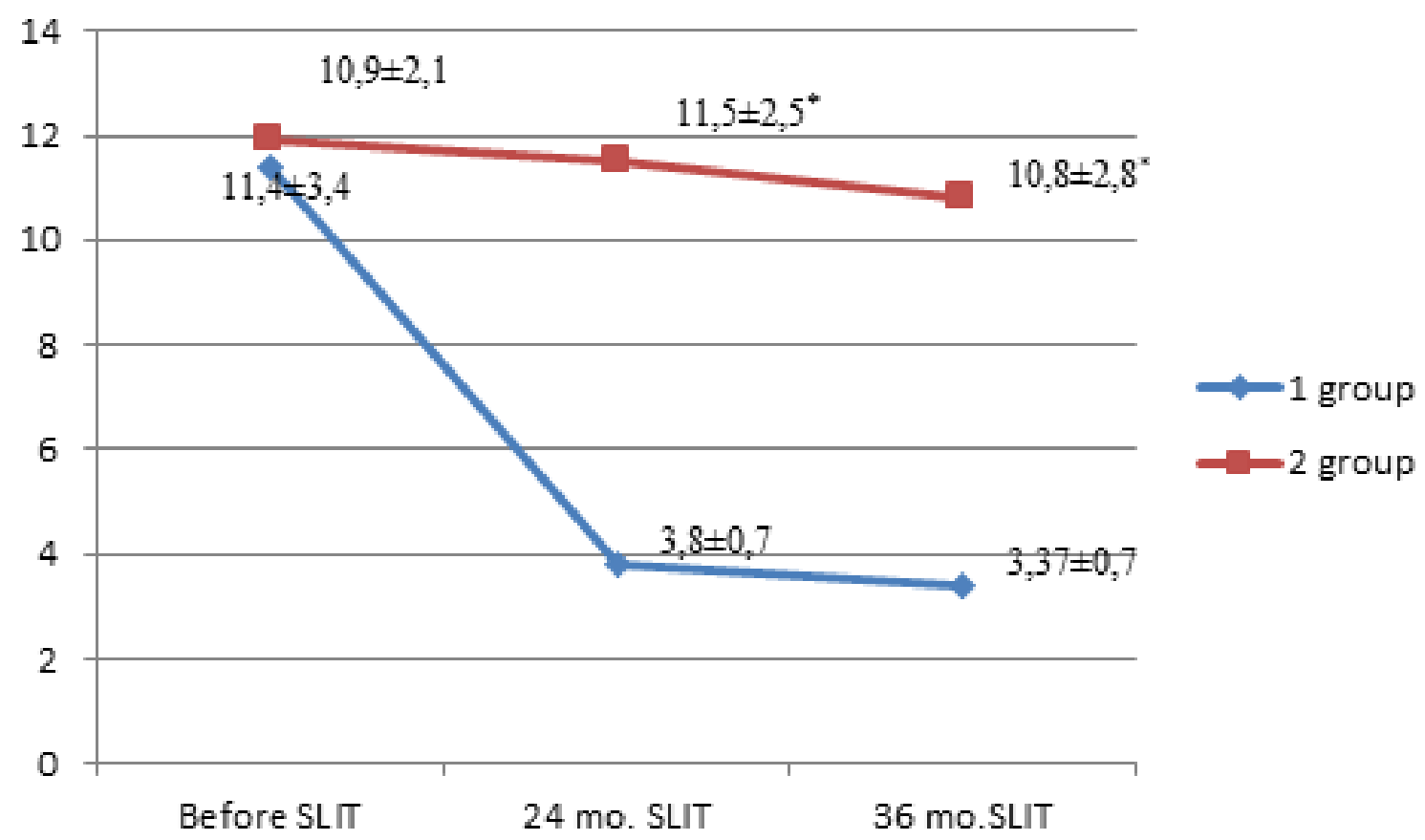

Figure 2. The number of respiratory virus diseases in children of the $1^{\text {st }}$ group after two and three years of SLIT

$* \mathrm{p}>0.05$ compared with indicators of children of group 2

\section{Conclusions}

1. A 3-year course of sublingual allergen immunotherapy with lyophilized epidermal cat allergens in children with allergic rhinitis and / or bronchial asthma was characterized by a significant improvement of the clinical symptoms and a decrease the level of Fel $d 1$.
2. The use of SLIT in children with allergic pathology associated with sensitization to cat epidermal allergens reduces the number of exacerbations and prevents the development of symptoms of allergic asthma in the preschool children.

3. Sublingual allergen immunotherapy in this study showed high safety and efficacy in 3-yearold children.

\section{References}

1. Allergen nomenclature WHO/IUIS Allergen Nomenclature Sub-Committee Financial contribution from IUIS, EAACI, and organizations http://www.allergen.org/viewallergen.php?aid=319

2. Allergic rhinitis is associated with poor asthma control in children with asthma / E. P. de Groot, A. Nijkamp, E. J. Duiverman, P. L. P. Brand // Thorax. - 2012. - Vol. 67. - Đ 582-587. doi:10.1136/ thoraxjnl-2011-201168

3. Bonnet et al. (2018) An update on molecular cat allergens: Fel d 1 and what else? Chapter 1: Fel d 1, the major cat allergen Allergy Asthma Clin Immunol. 14:14 https://doi.org/10.1186/s13223-018-0239-8

4. Sanny K., Chan Donald Y. M. Leung (2018) Dog and Cat Allergies: Current State of Diagnostic Approaches and Challenges Review Allergy Asthma Immunol Res. arch;10(2):97-105. https://doi.org/ 10.4168/aair.2018.10.2.97/

5. E. Ohotnikova, E. Sharikadze (2015) Bronchialnaya astma i allergicheskiy rinit u detey do 6 let osobennosti terapii kovorbidnoy patologii. Sovremennaya pediatriya. vol.8 (72). pp.111-116

6. Grönlund H, Saarne T, Gafvelin G, van Hage M. (2010) The major cat allergen, Fel $d$ 1, in diagnosis and therapy. Int Arch Allergy Immunol. Vol. 151(4):265-74. https://doi.org/10.1159/000250435

7. Jalil-Colome J, de Andrade AD, Birnbaum J, Casanova D, Mege JL, Lanteaume A, Charpin D, Vervloet D. (1996) Sex difference in Fel d 1 allergen production. J Allergy Clin Immunol vol. 98(1):165-8. Doi 10.1016/s0091-6749(96)70238-5

8. L. Romanuk (2013) Allergicheskiy rinit kak komorbidnoe sosnoynie bronhialnoy astmy. Astma ta alergiya. vol. 2. pp. 62-65. 
9. Liccardi G, Barber D, Russo M, D'Amato M, D'Amato G. Human hair: an unexpected source of cat allergen exposure. (2005) Int Arch Allergy Immunol vol.137(2):141-4. https://doi.org/10.1159/ 000085793

10. O.Sharikadze (2017) Particular quality of the treatment in the pre-school age children sensitized to house dust mites allergen. Inter collegas. Vol. 4(2). Pp 72-78.

11. J.P.M van der Valk, N.W. de Jong, R. Gerth van Wijk (2015) Review on immunotherapy in airway allergen sensitised patients The Netherlands Journal of Medicine. Vol.(6) pp 263-26.

12. S. Nedelska, D. Yarceva, V. Mazur (2013) Alergichnyi rynit ta bronchialna astma pylkovoy etiologii u ditey: retrospectivne doslidgennya clinichnogo perebigu Sovremennaya pediatriya. vol.1 (49). pp. 24-30.

13. Saarne T, Kaiser L, Gronlund H, Rasool O, Gafvelin G, van Hage-Hamsten M. Rational design of hypoallergens applied to the major cat allergen Fel d 1. (2005) Clin Exp Allergy vol. 35(5):657-63. https://doi.org/10.1159/000250435

14. T. Umanec (2015) Bronhialnaya astma I allergicheskiy rinit puti optimizacii complayensa i effectivnosti lecheniya. Astma ta alergiya. Vol.1. pp. 61-64.

Received: 21-Jul-2019

Accepted: 14-Nov-2019 